\title{
Socioeconomic Aspects of Child Labour- A Case Study of Children in Auto Workshops
}

\section{Rana Ejaz Ali Khan*}

\begin{abstract}
Federal Minister for Labour Manpower and Overseas Pakistanis, Omar Asghar Khan has announced the draft of the labour policy. The policy focuses on the law to eliminate child labour in the country. According to the Minister the law would be implemented from January 2001 and before the year 2005 there would be no child or bonded labour in Pakistan. Moreover, Under ILO obligation Pakistan has to achieve the objective of elimination of child and bonded labour by the year 2005. ILO plans to impose sanctions on the exports of those countries where child and bonded labour continues. Furthermore, the country has to abide with the convention of the International Labour Organization as a member of this $\operatorname{club}^{1}$.
\end{abstract}

Most of the studies about child labour in Pakistan are based on micro-data. The present study/survey is another addition to the previous studies with some additional variables. The focus of the study is socioeconomic aspects of child labour in auto-workshops, as 18 per cent of child labour is engaged in this establishment ${ }^{2}$. Some comparisons between the conclusions of the present survey and that of the previous ones have also been made. On the basis, policy recommendations have also been proposed.

\section{Introduction}

Child labour is prevalent in Pakistan in all sectors of the economy, though it mostly exists in the informal sector of employment and in the home-based industry. Pakistan is a developing country with per capita income of US\$ 480 and 12 per cent of the population lives below an income of US\$ 1 per day ${ }^{3}$. Pakistan has introduced legislation to eliminate child labour. Pakistan as a member of the ILO has signed a number of conventions. Even though various conventions and seminars have been held in the country, the problem still exists.

\footnotetext{
${ }^{*}$ Lecturer in Economics, Government Faridia College, Pakpattan

${ }^{1}$ The Daily "News" 24 November, 2000

2 NCCR-UNICEF [1998] Enforcement of Employment of Children Act 1991 in the North West Frontier Province, Pakistan

${ }^{3}$ UNICEF [1999] State of the World's Children 1999.
} 
The major sectors absorbing child labour in the country are manufacturing, transport, trade, agriculture, construction, and services. Child labour in the manufacturing sector (small scale and informal sector) is found in the sports industry, surgical goods industry, cottage industry, chemical industry, power looms, footwear industry, bidi making ${ }^{4}$, fisheries, carpet weaving, engineering and iron shops, furniture and fixtures. In the construction sector child labour is engaged in stone quarrying, building and road construction, steel shops, and the brick kiln industry. In the transport sector, child labour is found in auto workshops, service stations, and in garages as helpers, porters, loaders, and cleaners,. In the trade sector, it is found as shop assistants and street vendors. The agriculture sector absorbs child labour in fisheries, forestry, dairy and poultry farming, and agricultural labour. In the services sector child labour is found as domestic servants, cobblers, watch makers, electricians, mechanics, painters, tin packers, paper pickers, and trash pickers. It is found in hotels and restaurants as service boys, in laundry shops, barber shops, tailoring and embroidery shops as well.

Pakistan is essentially an agrarian economy, with most people depending on some form of agricultural activity for their livelihood. Within this context, it is common to find children playing an important economic role within the family. In the rural areas, agriculture is the main occupation, absorbing more than three-quarters of child labour. In urban areas, about three-fifths of child labour is engaged in production activities. Moreover, the rural and urban areas have different socio-economic conditions, so the determinants of child labour vary to some extent.

The estimates of child labour in Pakistan vary widely. Hussain [1985] estimated 14 million child workers, which makes 40 per cent of the child population of the country. Cochrane et al [1990] have calculated 31 per cent child labour force participation for boys and 7 per cent for girls in the age group 10-14 years. Ahmed [1991] referred to the Economic Survey 1988-89 and put the number of working children around 2.194 million in the age group 10-14 years, of which 2.01 million are actually working and 0.184 million seek work. He stated that the actual figure must be much higher as children under 10 years of age are not covered by this official estimate. Sathar [1993] has estimated 19 to 25 per cent of male child workers and 22 to 32 per cent of female child workers in the country.

Mahmood et al [1994] have estimated the magnitude of child labour in the country in the age groups of 5-9 years and 10-15 years. The children in the age cohort 5-9 years are most vulnerable to child labour, their physical, mental and conceptual development being critically jeopardised. In

\footnotetext{
${ }^{4}$ Curling tobacco leaves to smoke.
} 
the age group of 5-9 years, 39 per cent of the total population of children in this age group works. In the age group of 10-15 years, 77 per cent of the population of children works. For the entire age cohort of children 5-14 years, 58 per cent are working. This gives a child labour force of 19 million, of whom 7 million are below the age of 10 years, and another 12 million are between the ages of 10-14 years.

The estimates of child labour vary widely due to lack of systematic data collection and availability of micro-based data only. As most of the research work is based on case studies covering a few villages, a city, a subnational area, at best a province, state or an equivalent region.

The latest nation-wide survey of child labour was undertaken in 1996, by the Federal Bureau of Statistics in collaboration with the Ministry of Labour, Manpower and Overseas Pakistanis, and International Programme on the Elimination of Child Labour (IPEC) as a component of the International Labour Organization (ILO). The survey was the first of its kind in Pakistan. According to the survey, there are 40 million children in the age group of $5-14$ years, which is close to one-third $(30$ per cent) of the total population of the country. More than 50 per cent of the children are in the age group of 5-9 years. Among them the male children outnumbered female children with a sex ratio of 106 to 100 . In both age groups of 5-9 and 11-14 years, again male out-numbered female with a sex ratio of 107 and 105 to 100 , respectively. The majority of the children, i.e. 28.7 million (72 per cent) live in rural areas. Rural areas have relatively higher male/ female sex ratio than urban areas.

Among the 40 million children aged 5-14 years, 3.3 million, i.e. 8.3 per cent are economically active. According to the survey the volume of child labour is about 3.3 million of which 2.4 million ( 73 per cent) are boys and 0.9 million $(27$ per cent) are girls. The quantum of child labour increases with age, i.e. the older the child, the higher is the rate of labour force participation. The volume of male child labour is about 2.1 million in the age group of 10-14 years which is about seven times greater than the level of 0.3 million in the age group of 5-9 years. Similarly the volume of female child labour in the age group of $10-14$ years $(0.6$ million) is about three times greater than in the age group of $5-9$ years $(0.2$ million). It is also noted that male child labourers outnumbered female child labourers in both rural and urban areas. The ratio of rural areas in child labour is about eight times higher than that of urban areas. This may be due to unpaid farm activities performed by family members in the rural areas.

The provincial distribution indicates that the volume of child labour in the Punjab is about 1.9 million, which is about three-fifths (60 per cent) 
of the total child labour in the country. Next comes NWFP, which has about 1 million child labourers, and then Sindh with 298.30 hundred child labourers. The lowest figure of 13.72 hundred is for Balochistan, where less number of households have reported child labour'.

\section{Child Labour Legislation in Pakistan:}

Although the UN Convention deals with all the aspects of children's rights, there are six provisions, which apply directly to working children. These include the right to be protected from economic exploitation (Article 32 ), the right to be protected from abuse (Article 19), right to access to primary education, the right to be protected from all forms of harm, neglect and sexual abuse (Article 34), and the right to be protected from all forms of exploitation (Article 36). Collectively, these provisions try to protect children from adversity that accompanies child labour by shielding them from risks and abuses they encounter daily due to their vulnerability and unequal bargaining power. Despite Pakistan's ratification of the Convention, none of the above is observed in the case of child workers in auto workshops as is evident from the results.

After signing the 1990 International Convention on the Rights of the Child, the Government of Pakistan repealed the obsolete Employment of Children Act 1938 and enacted a new law called the Employment of Children Act 1991.

Part 1 of the Act defines children as persons below the age of 14 , which is at variance with the convention, that regards all persons below 18 as children.

Part 2 of the 1991 Act prohibits the employment of children in any occupation and process related to transport or ancillary operations, manufacturing of matches, crackers and fire works, bidi making, carpets, cement, cloth dyeing and weaving, mica, soap, wool cleaning, building and construction, slate and pencil (making and packing), agate products and toxic substances such as pesticides, chromium, benzene, asbestos, etc. However, the catch is that the above prohibition exempts cases where any of these hazardous occupations are carried on by a person with the help of his family members.

Part 3 of the Act permits child employment in occupations other than those mentioned above and attempts to regulate the conditions of work of children. Thus they are prohibited from working between 7 p.m. and 8 a.m.

${ }^{5}$ Federal Bureau of Statistics [1996] Child Labour Survey 1996, Government of Pakistan, Islamabad. 
The maximum working hours permitted are seven with a break of at least one-hour after three hours of continuous work. No overtime is allowed, nor is a child allowed to take up two jobs simultaneously. A working child is entitled to at least one weekly holiday. All establishments employing children are required by this law to notify the government about the nature of work and working conditions. These establishments are expected to conform to health and safety standards prescribed by the government and to ensure clean and hazardous free working conditions for children.

Part 4 of the 1991 Act prescribes for breach of any provision of the act by employers. These include imprisonment for a period extending to one year and a fine of up to twenty thousand rupees. While these penalties are more severe than those provided under the earlier child labour legislation, they are mild when we consider the impact on the health, safety and psyche of the child when the provisions are violated. Moreover, they are not enforceable against family members and unregistered establishments.

Manufacturing units employing less than 10 persons on a regular basis do not fall within the definition of factories and are not regulated by the factories act. Thus, the Employment Act of 1991 may at best help reduce the number of children employed in hazardous occupations in the formal sector where the overwhelming proportion of working children is actually employed ${ }^{6}$.

There is substantial child labour legislation in Pakistan, including the Employment of Children Act 1991 which established a minimum age and conditions of work in some occupations and bans child labour altogether in others. However, on the one hand these various laws and Acts have largely been ignored, and on the other many are so vague that they have left wide open room for legally perpetrated abuses.

The legislation for the protection of children lacks adequacy. The constitution prohibits the employment of children under the age of 14 in factories, and hazardous employment. There has so far not been a single court ruling interpreting the word "hazardous" under this article. Moreover, labour laws do not include labour in the agricultural sector and informal sector, where the majority of child labour is employed.

The penalty for employing children or for violating the regulatory provisions of the law is mild. The Workman's Compensation Act 1923 provided for Rs. 15,000 in case of death or injury to an adult labourer. For

\footnotetext{
${ }^{6}$ Hussain, Akmal [1997] Overcoming Poverty, in The News, August 3, 1997.
} 
children the compensation is Rs. 4,000. Persons pledging children for work are fined Rs.50, those who accept a pledged child are fined Rs. $200^{7}$.

Determinants of Child Labour:

Several formal models [Levy (1985), Rivera-Batiz (1985) and Sharif (1994)] of the household economy take into account the economic contribution of children to household income to explain the decision of supply of child labour by parents.

Although the data on the remuneration of child workers is scarce and investigations on child labour supply have found mixed evidence, the general conclusion seems to be the same that the children are paid less than adults, even when they perform the same task [Bequele and Boyden 1988; Jomo 1992]. The effect of lower earnings on child labour depends on the wage elasticity of child labour supply, and here too the evidence is mixed. Some studies find that employers have no difficulties recruiting children even at very low wages, while others find elasticities in the range of 0.8 to 1.0 , although elasticities seem to be lower for older children [Levy 1985; Rosenzweig 1981]. Still low wages of children is a cause of demand for children as workers.

Many researchers have focused on the determinants of schooling attendance to analyse the reasons for child labour, even recognising that school attendance is not the "inverse" of child labour. Children who are not enrolled in school are not necessarily involved in child labour activities, while many children who are enrolled in school also work, either in household enterprises or after school hours. In some cases schooling problems contribute to child labour. The inaccessibility of schools or their poor quality often spurs parents to engage their children in work. And many children may have to work in order to afford the direct costs associated with school attendance, such as fees and school books. Cost of schooling enhances the supply of child labour [Abdalla 1988].

Schooling facilities negatively affect the supply of child labour. Schooling facility is a function of the cost of schooling, government expenditures on education, private schooling system, the quality of education, job orientation of education and the distance of school from home.

\footnotetext{
${ }^{7}$ Jahangir, Asma [1989] Children of Pakistan-The Defacto Situation
} 


\section{Methodology and Survey}

\section{Objectives:}

The study is carried out to ascertain:

1. Socio-economic background of child labour and the employers in auto workshops

2. The reasons why these children work and the reasons for leaving school

3. The element and the extent of exploitation, i.e. working hours, midday break, physical punishment, amount of payment, and mode of payment, etc.

4. The utilisation of children's income as contribution towards family income

5. The extent of awareness concerning children's rights amongst the children and their employers

6. Recommendations for effective solutions of the issue

\section{Data Collection:}

A comprehensive interview schedule was developed. It comprised various dimensions of the issue involved in the problem of child workers in auto workshops. To take an in-depth understanding of various issues, and to investigate the unexpected aspects of the problem, the technique of Focus Group was involved.

\section{Child's Perspective}

A structured interview schedule was developed. It had questions pertaining to various dimensions of the issue of child labour in auto workshops, such as demographic information, school history, reasons for leaving school, previous work history, duration of present job, reasons for working and economic aspects, psychological environment, and working conditions, etc

\section{Employer's Perspective}

The structured interview also included a part to investigate the perspective of employers of the children or the owners of the workshop. 
The employers were asked the reason for employing children, wage structure and pattern, the benefits provided to the child in addition to wages, leisure, etc. The survey was conducted in 60 auto workshops of district Pakpattan. The workshops surveyed were of rural and urban areas and the sample was selected randomly.

The children were classified into three categories according to their age group, i.e. less than 8 years, 9 to 11 years, and 12 to 14 years. The workshops were categorised into two types. First, heavy vehicle workshops such as tractors, trailers, trucks, lorries and mini buses etc. Secondly light vehicle workshops such as cars, jeeps, rickshaws and motorcycles etc. Another classification of workshops was the authorised workshops by manufacturing companies and non-authorised workshops.

The data was selected through interviewing the children individually through the structured interview schedule. Preferably the employer was not allowed to be present while interviewing the child. Similarly, by interviewing the owner of the workshop or Ustad the information was collected. The response rate was more than ninety per cent.

\section{Results and Discussion}

An analysis of child labour in auto-workshops reveals that:

- Child labour in auto workshops ${ }^{8}$ is 30 per cent i.e. a relatively higher incidence of child labour in this category

a There is extensive violation of the Convention on the Rights of the Child and Employment of Children Act 1991

a Child labour also exists in authorised workshops, i.e. either the companies and corporations do not have their code of conduct regarding child labour or do not obey it

a Child labour exists equally in heavy as well as light vehicle workshops

The detailed results are shown in the tables. The age groups of the sample are shown in Table No. 1. The average statistics of the child labourers are discussed in Table No 2. The working conditions are discussed in Table No. 3. Table No 4 and 5 gives information about the perspective of the father/head of household of working children. Household size of the child labourers is shown in Table No. 6. The reasons for leaving school and starting work is shown in Table No. 7 and 8.

\footnotetext{
${ }^{8}$ Ratio of children to total workers in auto workshops (in percentage)
} 
Table-1: Child Labour in Age Groups

\begin{tabular}{lcc}
\hline \multicolumn{2}{c}{ Age Group (Years) } & $\begin{array}{c}\text { No of Children } \\
\text { (Percentage) }\end{array}$ \\
\hline 1. & -8 & 12.5 \\
2. & $9-11$ & 37.5 \\
3. & $12-14$ & 50.0 \\
\hline
\end{tabular}

It is evident from the above table that child labour participation in auto-workshops increases with increase in age.

Table-2: Average Statistics of the Children

\begin{tabular}{llll}
\hline Age & 11 Years 01 Month 13 Days \\
Income & Rs. $32.88 \quad$ Per Week & \\
Daily Working Hours & 11.45 Hours & \\
Duration of Midday Break & 27.17 Minutes & \\
Working Experience of Children & 2 Years 01 Month 04 Days \\
Time to Complete the Training & 3 Years 11 Months 19 Days \\
Distance of Workshop From Home & 3.5 K.m & \\
Completed Years of Schooling & 3.9 Years & \\
\hline
\end{tabular}

It was found that the wages were paid weekly and no child or parents have taken an advance as against many other forms of child labour, like child labour in carpet weaving, in brick kilns and in agriculture. It shows:

․ There is no bonded child labour in auto workshops

- Under market forces employers do not give advance due to abundance of supply of children as compared to demand

- The parents or children do not take advance due to the perception that the job is apprenticeship type, moreover they consider skill acquirement is better than education from the point of view of employment, as formal education does not guarantee a job.

All the above factors keep the wages of children low.

The number of hours that children work is critically important. Fatigue is a major cause of accidents and can impair intellectual development. The daily working hours (11.45) calculated in the present study are higher than calculated by Khan [1982] and Awan and Khan 
[1992]. The fact is that the survey was conducted in the months of April and May, which have longer days than the winter season. But the result exactly matches the results by Chand[1983].

The midday break is less than an hour, and is a lunch break and rest. The employers provide lunch for the majority of the children.

Average years of child's experience estimated in the present study is two years. According to the employer, it needs approximately four more years on average to complete the training. This means the total duration of training is six years. Such a long period of training with a long working day for a skill suggests a number of possibilities that may be

口 The trainee is dull, not interested in the skill, unable to learn properly or the learning is very difficult

a The skill master is not interested in their learning, unable to teach, intentionally delays the period

- The major part of the job is work, not learning

Most of the child workers come from far distances, as the average distance from home to workshop is 3.5 kilometers. It is also noted that the majority of the children ( 75 per cent) come on foot. Only 4.75 per cent use bicycles and approximately the same percentage use a bus or other public transport. If the time consumed in travel is included in job activities, the daily working hours will exceed the calculated hours.

The average completed number of years of schooling by working children indicates that the majority of the children have not completed the primary level of education.

Table-3: Percentage Statistics of Children

\begin{tabular}{lc}
\hline (Children) & (Percentage) \\
\hline Beaten up by the Employer or Ustad & 95.65 \\
Live in the Workshops & 7.5 \\
Occasionally Live in the Workshops & 4.5 \\
Enrolled in Formal Education & Nil \\
Fathers are employers & 4.16 \\
\hline
\end{tabular}


The factors which contribute to make work hazardous are the age of the child, the hours and conditions of work, and the physical and psychological strain of the activity. A large majority of child workers $(95.65$ per cent) accepted that the employers beat them up.

The data reveals that 7.5 per cent of the child workers do not go back to their home everyday and sleep in the auto-workshops, while 4.5 per cent of children have to live in workshops occasionally due to workload. They are provided only a little place to sleep.

None of the children is enrolled in formal education. This means that child labour in auto-workshops have such difficulties that to combine education with work is not possible. A number of likely reasons are:

a Children have no time to attend lessons due to long working hours

on-availability of teachers and informal education

a Fatigue does not make it possible for the children to think about education

Table-4: Occupation of Father

\begin{tabular}{llc}
\hline & \multicolumn{1}{c}{ Type of Occupation } & Percentage \\
\hline 1. & Employers & 31.18 \\
2. & Farmer with Land ownership & 27.27 \\
3. & Wage Earners & 18.18 \\
4. & Self-employed Non-agriculture & 15.59 \\
5. & Landless Farmers & 13.63 \\
6 & Government Employee & Nil \\
& Total & $\mathbf{1 0 0 . 0 0}$ \\
\hline
\end{tabular}

The highest number of children, that is 31.18 per cent, come from households where fathers/head of the households are engaged in private employment. It may be inferred that the job is not secured or the source of income is not secured. So the households supply their children as labourers. Second highest proportion (27.27) come from the farmers with land ownership. This is not surprising because all these households have a small piece of land, as they have the capital, so their source of income should be secured. But the small holding of land is insufficient to support the family so the children are supplied as labourers. Moreover, the seasonal conditions in the income of the farmers support the option of child labour. These 
104 The Lahore Journal of Economics, Vol.6, No.1

conditions lead to the decision of the head of the households to engage their children in skill acquiring as against engaging them in agriculture. The fluctuation in income enhances the supply of child labour, the point is supported by the evidence that child labour supply is nil from the households having head of the household as government employee.

As concerns the land-less farmers, they should supply child labour more as compared to the farmers with land ownership, due to the fact that households with no capital are relatively more vulnerable and poor. In fact, these farmers may have more desire to engage their children in such type of work but their landlords do not spare the children. The landlords keep them engaged in unpaid activities.

15.59 per cent of child labour come from self-employed nonagriculture households and only 9 per cent children come from unemployed households. It contradicts the conventional approach that unemployment is the major cause of supply of child labour.

Table-5: Education of Fathers

\begin{tabular}{llc}
\hline & Years of Education & Percentage \\
\hline 1. & Nil (Illiterate) & 42.85 \\
2. & $1-5$ & 33.35 \\
3. & $5-8$ & 14.28 \\
4. & $9-10$ & 4.76 \\
5. & $11-12$ & 4.76 \\
6. & $13-14$ & Nil \\
& Total & $\mathbf{1 0 0 . 0 0}$ \\
\hline
\end{tabular}

The highest proportion of child labour $(42.85$ per cent $)$ come from illiterate families. In the present study the average completed years of education of fathers is 3.95 years. It is also evident from the results that the increase in the education of the head of the household decreases the incidence of child labour. Hamid [1994] has also given the same results. 
Table-6: Households (Who Supply Child Labour) with Children

\begin{tabular}{cc}
\hline No of Children & Household (Percentage) \\
\hline 1 & 0.00 \\
2 & 4.16 \\
3 & 0.00 \\
4 & 5.10 \\
5 & 12.50 \\
6 & 16.66 \\
7 & 20.83 \\
8 & 12.50 \\
9 & 4.16 \\
10 & 4.16 \\
\hline
\end{tabular}

The results in the table show another reason to leave school and put the child to work, that is larger families. The size of the family was mostly large in the survey. It is found that 20.83 per cent of the working children come from families having 7 offspring. Similarly 16.66 and 12.5 per cent come from households with 6 and 5 children respectively. The more the children, the more the parents are unable to provide them better options, that is why they choose to work. The study gives the clue that the families with large number of children cannot afford schooling expenditures of all the children so some children work to support themselves and school going children of the household. It is also calculated in the present study that the average number of children per household (who supply child labour) is 5.95. Lloyd [1994] described that the larger household size increases the probability of child labour. It may be concluded that inadequacy of a family planning programme can also be attributed to the existence of child labour.

Table-7: Reasons for Leaving School

\begin{tabular}{llc}
\hline & \multicolumn{1}{c}{ Reasons } & Children (Percentage) \\
\hline 1. & Lack of Resources & $\underline{48}$ \\
2. & Lack of Interest in Education & 32 \\
3. & Beaten up by the Teacher & 8 \\
4. & Parent's Preference for Work & $\mathbf{1 0 0}$ \\
& Total & 8 \\
\hline
\end{tabular}


Since schooling is the main factor demanding time, it stands to reason that the cost of schooling would be an important determinant of the likelihood of child work [Siddiqi and Patrinos 1995].

Siddiqi and Patrinos [1995] view schooling as the most important means of drawing children away from child labour. The type and amount of work a child performs can directly affect school performance. The more vigorous and time consuming the work, the more likely that the child will score poorly on tests, miss school, and repeat grades. The children who work continuously from a very young age are also more likely to drop out of school after having completed only a minimum level of education.

Harsh attitude of teachers, high schooling cost and lack of interest in education propels dropouts and so the supply of child labour [Chand 1983]. Children are forced to work due to lack of education facilities [Ahmed 1991]. Lack of schooling facilities propels child labour [Bonnet 1993]. Children work because of non-availability of schools compounded by the poor quality of education [Bequele and Boyden 1988]. The extreme poverty of households contributes to low school enrolment rates. The parents commented that since schooling did not guarantee better jobs for their children, it is better to send them to work [Salazar 1988].

In the survey, children who had left school were asked to highlight the reason for leaving school. Most of them replied that it was due to lack of resources. The second reason given was the lack of interest in education. Some children revealed the reason for leaving the school as being beaten up by the teacher. The above two reasons reveal that at least their parents had attempted to educate them but did not succeed.

There are 8 per cent children who work because their parents removed them from school and preferred work, which indicates the helplessness of these children. They are expected to accept the double authority of fathers, as a parent as well as the master employer.

Table-8: Reasons for Employers Employing Children

\begin{tabular}{llc}
\hline & \multicolumn{1}{c}{ Reasons } & Employers (Percentage) \\
\hline 1. & Lower wages & 50 \\
2. & Training purpose & 25 \\
3. & Parents insistence & 25 \\
4. & Both for training and lower wages & 40 \\
5. & Children suit the job & Nil \\
\hline
\end{tabular}


The majority of the employers ( 50 per cent) accepted that they kept children due to lower wages. A slightly less than the above number of employers gave the reason as both training and low wages.

Skill acquirement by children positively affects the supply of child labour. The children as well as the parents consider the work as vocational training so parents send their children to work and children show their willingness [Hafeez 1979]. The majority of the children hopes that their participation would enable them to learn a skill for the future [Abdalla 1988].

It was also found that some of the employers said that children are employed due to the insistence of the parents of the children. The reason is given in Table No. 7 that these children work due to parents' preference for work but it seems that the employers disguise the implicit meaning that they are easily available, less demanding and easily exploited economically.

No employer gave the reason that the job is more suitable for the children.

\section{Conclusion}

Child labour engaged in auto workshops is considered to be apprentice type so the wages are comparatively lower than other types of child labour. The finding matches the results of other studies'.

Growing children are eager to learn about the world, about its dynamics and its wonders, its customs and its rules. They absorb information with miraculous ease, as if knowledge itself were fuelling their development, learning from the world around them, from school, from play, from parents, from teachers, from other children and sometimes also from work. What kind of learning, however, is a child to imbibe from work in auto workshops with long daily working hours with a short midday break, beaten up by the employer, and sleeping in workshops in isolation from the family. The situation violates most of the rights in the Convention on the Rights of the Child and basic humanity.

The general observation indicates the poor health of the children, bad, smoky, dusty and dirty surroundings of the work places. Moreover 8.3 per cent of the workshops are roadside workshops and most of them are puncture shops.

It has also been found that the income of these children is not fully utilised in the household expenditures, only 45 per cent of them give their

\footnotetext{
${ }^{9}$ Khan, Shaheen [1982]
} 
salary to their mothers or fathers. They only partly contribute to their families.

The majority of the children left school due to poverty, lack of interest in education and harsh attitudes of the teachers.

The lower value of Standard Deviation of wages of children shows that the employers have fixed the wages collectively so the market forces work for the uniformity of wages in auto workshops.

None of the children believe that schooling is good, which is exactly contradicted by the results of Khan [1982] where the majority of the children believe schooling to be good. This indicates that the working children are unaware of their exploitation and work seemed to them an opportunity to learn skills to acquire better jobs. The result matches the findings of Hafeez [1988].

As the average income of the father/head of the household calculated in the present study is Rs. 1965 per month only, that is the child labour producing families fell in the lowest quintile of income groups. The majority of children come from poor families and poverty a main cause of child labour has already been revealed in the studies by Hafeez [1988], Chand [1983], Hussain [1993], Grootaert [1998] and Chaudhry [1998]. Hamid [1994] narrates that the majority of the children (37 per cent) fell in the lowest income group of less than Rs. 200 per month.

\section{Recommendations}

As the parents of children consider that the children in auto workshops are being trained, formal education along with training may be a better option instead of total elimination of child labour at once. For the purpose, afternoon and evening schools must be organised for working children. Setting up research and monitoring centers for children is also needed.

Finding out about child labour to determine the exact magnitude, nature and effects, a thorough qualitative analysis of the specific groups of child labour and their working and living conditions also needs to be done. Training on design management and evaluation of child labour projects and programmes are proposed.

Promoting the welfare and development of the children, protecting the working child and providing health and social welfare services are 
proposed. Moreover, withdrawing, rehabilitating, offering alternatives and/or compensating child labourers are also required.

The study proposes the elimination of the economic, social and physical exploitation of child labourers. It stresses on the provision of protection from performing work that hampers their physical and mental development. Advocating effective laws and their enforcement and assisting in identification of contraventions of the law, to control factors that generate the demand for child labour as well as that generate the flow of children into the workforce is required.

Education should be in easy access to the poor and financial support in the shape of less expensive education should be provided. Physical punishment of all sorts should be strictly prohibited in educational institutions and the offender be given appropriate penal punishment. The rights of the child should be made a part of the teacher's training curriculum and also be given exposure in school curriculum. Motivation of school teachers should be improved through improvement in salaries, working conditions, housing, etc. and arrangements for training and supervision of their work.

The schools should develop strategies with which the illiterate parents should not feel left out. A more encouraging and supportive attitude towards the children, whose parents are not educated is proposed. Parents with children between 5 to 7 should be given special encouragement to send their children to schools.

NGOs working for the rights of children should concentrate on this segment of neglected children. They should design campaigns to make the public, policy makers and parents aware of the serious repercussions on a child's future once exposed to physical, sexual or economic abuse.

Employer's organisations can play an important role by helping business and industries using child labour to improve their efficiency and competitiveness through production and personnel practices that increase incentives for adult workers and decrease reliance on children. Firms need to establish their own codes of conduct that prohibit the direct and indirect employment of children. 
110 The Lahore Journal of Economics, Vol.6, No.1

\section{References}

Abdalla, Ahmed, 1988 "Child Labour in Egypt: Leather Tanning in Cairo" in Bequele and Boyden (ed) Combating Child Labour. ILO, Geneva.

Ahmed, Manzooruddin, 1991 "Child Labour - A Time to Reflect” UNICEF, Pakistan and Govt. of Balochistan, Pakistan.

Ali, Karamat and Abdul Hamid, 1999 "Major Determinants of Female Child Labour In Urban Multan (Punjab-Pakistan)" Department of Economics, Bahauddin Zakariya University, Multan. Processed.

Awan, Saeed A. and Abid Ali Khan, 1992 "Child Labour in Carpet Weaving Industry in Punjab" UNICEF, Punjab in collaboration with Center for the Improvement of Working Conditions and Environment, Lahore.

Bequele, A. and J. Boyden (eds), 1998 “Combating Child Labour" ILO, Geneva.

Bonnet, Miche1, 1993 “Child Labour in Africa” International Labour Review (Geneva) 132(3):371-389.

Chand, Raja, 1983 "An Explanatory Study of Fifty Children Working in Auto Workshops" Department of Social Work, University of the Punjab, Lahore.

Chaudhry, M. A. K., 1998 “Child Labour - Facts And Fiction” Labore Journal of Economics (Lahore) 2(2).

Cochrane, S., V. Kozel and H. Alderman, 1990 "Household Consequences of High Fertility in Pakistan” World Bank Discussion Paper \# 111. The World Bank, Washington, D.C.

Grootaert, Christiaan, 1998 "Child Labour in Cote d' Ivoire: Incidence and Determinants” Policy Research Working Paper \# 1905. The World Bank, Washington, D.C.

Hafeez, Sabeeha, 1979 "Some Aspects of Child Labour in Pakistan" Department of Sociology, University of Karachi, Karachi.

Hafeez, Sabeeha, 1991 “The Changing Pakistan Society” Royal Book Company, Karachi. 
Hamid, Shahnaz, 1994 "A Micro Analysis of Urban Child Labour: Some Determinants of Labour and Its Conditions" The Pakistan Development Review (Islamabad) 33 (4). Part II Winter.

Hussain, Akmal, 1985 "Child Labour in Lahore" A Survey Sponsored by Sayyed Engineers, Lahore.

Hussain, Akmal, 1998 "Child Workers in Hazardous Industries in Pakistan" The Lahore Journal of Economics (Lahore) 2(2).

Jahangir, Asma, 1989 "Children in Pakistan - The Defacto Situation" in Child Abuse in Pakistan, Report of the Seminar organised by Pakistan Paediatric Association NWFP (Peshawer) with the collaboration of UNICEF.

Jomo K. S. (ed), 1992 Child Labour in Malaysia Varlin Press, Kuala Lumpur.

Khan, Shaheen, 1982 "Compelled Child Labour in Punjab: A Case Study" Punjab Economic Research Institute, Lahore.

Khan, Shaheen, 1982 "Labour Force Participation of Children: A Case Study" Pakistan Social and Economic Review, Summer.

Levy, Victor, 1985 "Cropping Pattern, Mechanization, Child Labour and Fertility Behavior in A Farming Economy: Rural Egypt" Economic Development and Cultural Change 33.

Lloyd, Cynthia B. (ed), 1994 "Investing in the Next Generation: The Implication of High Fertility at the Level of the Family" Research Division Working Paper \# 63. New York Population Council, New York.

Moazam, Mahmood, 1994 "Why Do Children not Go to School in PakistanSome Estimates and A Theoretical Framework" The Pakistan Development Review (Islamabad) 33 (4):581-592. Part II. Winter.

NCCR and UNICEF, 1998 "Enforcement of Employment of Children Act 1991 in North West Frontier Province" Pakistan. National Coalition on Child Rights (NCCR) and UNICEF, Peshawer.

Rivera-Batiz, F. L., 1985 "Child Labour Patterns and Legislation in Relation to Fertility” Mimeo: Department of Economics, Indiana University, Bloomington. 
112 The Lahore Journal of Economics, Vol.6, No.1

Rosenzweig, Mark R., 1977 "The Demand for Children in Farmhouses" Journal of Political Economy.

Salazar, Maria Cristina, 1988 "Child Labour in Colombia: Bogota's Quarries and Brickyards” in Bequele and Boyden (ed) Combating Child Labour. ILO, Geneva.

Sathar, Zeba A., 1993 "Micro-consequences of High Fertility: The Case of Child Schooling in Rural Pakistan” in Cynthia B. Lloyd (ed) Fertility, Family Size and Structure: Consequences for Families and Children. Proceedings of Population Council Seminar, New York 9-10 June, 1992. New York Population Council, New York.

Sharif, Muhammad, 1994 "Child Participation, Nature of Work and Fertility Demand: A Theoretical Analysis” Indian Economic Journal 40 (4).

Siddiqui, F. and H. A. Patrons, 1995 "Child Labour: Issues, Causes and Interventions" Education and Social Policy Department Discussion Paper \# 53. The World Bank, Washington, D.C. 